\title{
Adsorption/reaction energetics measured by microcalorimetry and correlated with reactivity on supported catalysts: A review
}

\author{
Lin Li a, Jian Lin a , Xiaoyu Li a,b, Aiqin Wang a , Xiaodong Wang a,*, Tao Zhang a \\ a State Key Laboratory of Catalysis, Dalian Institute of Chemical Physics, Chinese Academy of Sciences, Dalian 116023, Liaoning, China \\ b University of Chinese Academy of Science, Beijing 100049, China
}

\section{A R T I C L E I N F O}

\section{Article history:}

Received 22 September 2016

Accepted 14 Octomber 2016

Published 5 December 2016

\section{Keywords:}

Catalysis

Microcalorimetry

Reactivity

Energetics

Binding strength

Catalyst characterization

\begin{abstract}
A B S T R A C T
The formations and transformations of the chemical bonds of reactants and intermediates on catalyst surfaces occur in conjunction with the evolution of heat during catalytic reactions. Measurement of this evolved heat is helpful in terms of understanding the nature of the interactions between the catalyst and the adsorbed species, and provides insights into the reactivity of the catalyst. Although various techniques have previously been applied to assessments of evolved heat, direct measurements using a Tian-Calvet microcalorimeter are currently the most reliable method for this purpose. In this review, we summarize the relationship between the adsorption/reaction energetics determined by microcalorimetry and the reactivities of supported catalysts, and examine the important role of microcalorimetry in understanding catalytic performance from the energetic point of view.
\end{abstract}

(C) 2016, Dalian Institute of Chemical Physics, Chinese Academy of Sciences. Published by Elsevier B.V. All rights reserved.

\section{Introduction}

During the reactions of molecules over a catalyst, there are significant interactions between these molecules and the catalyst surface. The reactivity of a catalyst is therefore highly dependent on the strength of such interactions. According to the Sabatier principle, the ideal catalyst will bind reaction intermediates with sufficient strength to activate the reactants but not so strongly that desorption of the products is inhibited [1]. Thus, investigations of the binding of reactive molecules with catalyst surfaces can provide important insights into the reactivity of the catalyst.

A heterogeneous catalytic reaction is initiated by the formation of bonds between the reactant and the solid catalyst surface, accompanied by the release of heat. The evolved heat, defined as adsorption heat, is related to the bonding strength, and therefore to the reactivity of the catalyst. Adsorption heat can be obtained indirectly by methods such as temperature-programmed desorption (TPD) and isothermal adsorption [2]. However, in many cases, adsorbed species will decompose rather than undergo desorption when using these methods. Furthermore, the application of heat during the desorption process can also induce structural changes or even the decomposition of the catalyst before the adsorbed species desorb. In addition, these techniques only provide the isosteric heat of adsorption, which does not give any information regarding the surface energy heterogeneity [3]. These shortcomings therefore limit the applications of such methods to the measurement of adsorption heat.

With the development of commercial calorimeters, the as-

\footnotetext{
* Corresponding author. Tel: +86-411-84379680; Fax: +86-411-84685940; E-mail: xdwang@dicp.ac.cn

This work was supported by the National Natural Science Foundation of China $(21573232,21576251,21676269)$, National Key Projects for Fundamental Research and Development of China (2016YFA0202801), and Department of Science and Technology of Liaoning province under contract of 2015020086-101.

DOI: 10.1016/S1872-2067(16)62578-0 | http://www.sciencedirect.com/science/journal/18722067 | Chin. J. Catal., Vol. 37, No. 12, December 2016
} 
sessment of adsorption heats using microcalorimeters based on the Tian-Calvet principle has become the most reliable method for this purpose [3-5]. Through the judicious choice of gas phase probe molecules, analogies between the adsorption energetics of these probe molecules and the properties of the active sites on catalysts can be established. As an example, the adsorption energetics of basic compounds such as ammonia and pyridine on zeolites and metal oxides provide a better understanding of the acidic sites on such materials [6,7]. As well, the adsorption heats of $\mathrm{CO}$ on metal catalysts can be related to the metal-carbon bond strengths in hydrocarbon reactions [8].

Microcalorimetry has, in fact, been employed for surface science and catalysis studies since the 1930s, and some excellent reviews regarding fine wire and single-crystal model systems [9-11] and analyses of supported catalysts [6,7,12-14] have been published. Nevertheless, an overview of the direct relationship between adsorption/reaction energetics and reactivity on supported catalysts is still lacking. In this review, we firstly introduce the various microcalorimetric techniques used for measurements of adsorption/reaction energetics. Following this, we summarize the applications of microcalorimetry to determining the adsorption/reaction energetics on supported catalysts, and discuss the relationships between reactivity and the quantities and strengths of active sites, the binding strengths of reactants, intermediates and products, and the reaction energetics. Finally, conclusions and future microcalorimetric applications in catalysis research are presented.

\section{Instrumentation}

\subsection{Adsorption microcalorimetry}

Adsorption microcalorimetry is the most widely used calorimetric method for the measurement of heats of adsorption on supported catalysts, and various instrumental setups have been reported [15-21]. A schematic diagram showing a typical adsorption microcalorimetry apparatus is shown in Fig. 1. The instrumentation usually consists of a microcalorimeter, based on the Tian-Calvet or heat-flow principle, capable of operating over a wide temperature range. This microcalorimeter is attached, by way of various types of calorimeter cells made from glass or stainless steel, to a volumetric system. The volumetric

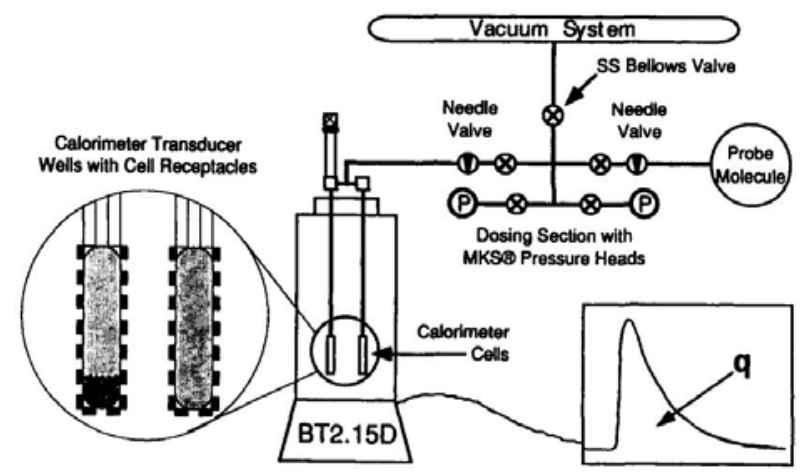

Fig. 1. Schematic diagram of a typical adsorption microcalorimetry apparatus [16]. apparatus includes a high vacuum system, various probe molecule reservoirs, and a calibrated dosing volume with MKS pressure heads. In a microcalorimetric experiment, small doses of gaseous probe molecules are successively introduced onto the surface of the catalyst. The evolved heat and corresponding adsorption amount at each dose are measured by the microcalorimeter and the volumetric system, respectively. The resulting plot of adsorption heat as a function of probe molecule uptake provides information concerning the distribution of interaction strengths over the catalyst surface. In addition, the saturation uptakes obtained from adsorption measurements can be interpreted to obtain data regarding the quantity of accessible surface sites.

The amount of the probe compound that is adsorbed is usually determined based on a volumetric method. For this reason, it is possible to obtain an inaccurate value for the amount adsorbed when reactions of the probe compound occur rather than simple adsorption, leading to artifacts in the differential plot of heat as a function of surface coverage [22]. This possibility limits the accuracy of such measurements in those cases in which reactions do take place, and various alternative microcalorimetric setups have been developed to address this issue [23-27].

\subsection{Gas flow-through microcalorimetry}

A commercial MICROSCAL FMC gas flow-through microcalorimeter is one alternative approach to measure the energetics of a catalyst, working in the flow mode $[23,24]$. In this method, the sample is placed in a calorimetric cell that is subsequently purged with high purity $\mathrm{He}$ until thermal equilibrium is reached. At this point, the He stream is replaced by a reactant molecule flow and the adsorption/reaction experiment is initiated. The experiment is ended when the heat evolution is observed to plateau, indicating no further adsorption/reaction of the probe molecules. In a final step, desorption is performed by switching the probe flow back to a He purge. The flow rates of the helium and the probe are tightly controlled during the entire process, typically at values in the range of $3-7 \mathrm{~cm}^{3} / \mathrm{min}$. A thermal conductivity detector (TCD) can be used to measure the amount of the probe compound that is adsorbed or desorbed, and this method makes it possible to determine both the reaction and adsorption energetics. Nevertheless, flow-through microcalorimetry often allows one to determine only the average heat output of the adsorption process.

\subsection{In situ pulse microcalorimetry}

Differential adsorption/reaction energetics can also be obtained by in situ microcalorimetry, working in the pulse mode $[25,26]$. In contrast to gas flow-through microcalorimetry, in situ pulse microcalorimetry introduces a series of successive small pulses of probe molecules to the catalyst surface until saturation is achieved. This technique employs a Tian-Calvet microcalorimeter coupled with a pulse microreactor system, as shown in Fig. 2. In this apparatus, a specially designed calorimetric cell, in which samples are pretreated in situ, is connect- 


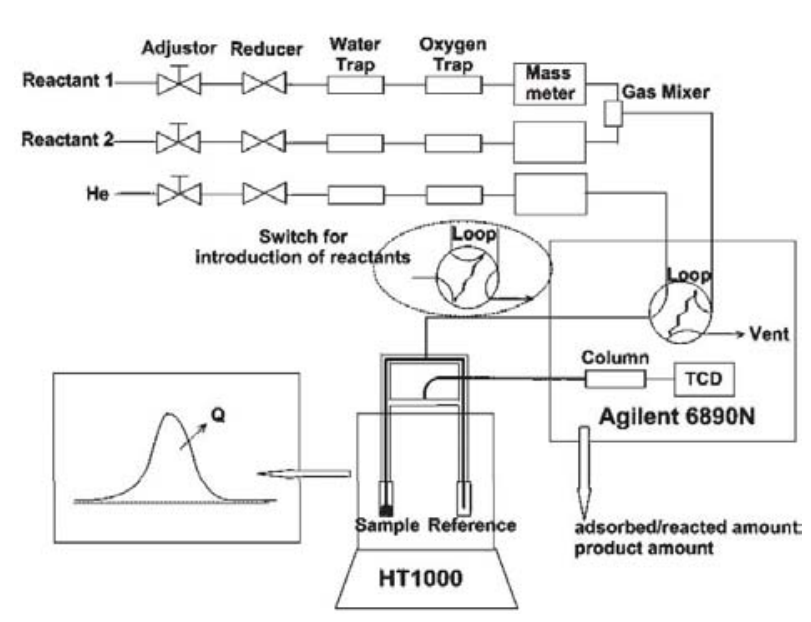

Fig. 2. Schematic diagram of the apparatus for in situ pulse calorimetric measurement of adsorption/reaction processes [26].

ed to the six-way valve of a gas chromatograph. Doses of the probe compound can be introduced one after the other to the catalyst surface via a gas loop with a known, corrected volume while the sample is maintained at the desired temperature. The heat evolved in response to each individual pulse of the probe compound as the result of either adsorption or reaction is measured by the microcalorimeter, while the amounts of unreacted probe compound and of products are analyzed using the gas chromatograph.

Although reaction energetics can be obtained using either flow-through or pulse microcalorimetric setups, it is still challenging to interpret the energetics associated with a catalytic cycle. It is necessary to obtain the greatest possible amount of energetic data as well as to perform various complementary studies based on other characterization techniques so as to better understand the reaction energetics.

\section{Catalytic applications}

The elucidation and quantification of the active sites on supported catalysts is of paramount importance in the study of heterogeneous catalysis [28]. Although many techniques, such as X-ray photoelectron spectroscopy and transmission electron microscopy, have been used for this purpose, the quantification of active sites is still a difficult task. One significant advantage of microcalorimetry, especially combined with the adsorption of probe molecules, is that it provides quantitative information regarding the interaction strength, quantity and energetic distribution of active sites. As an example, the strength and number of acidic sites can be determined using basic compounds such as $\mathrm{NH}_{3}$ or pyridine [29], while acidic molecules such as $\mathrm{CO}_{2}$ or $\mathrm{SO}_{2}$ can be used for the characterization of basic sites [30]. As well, microcalorimetry can be employed to assess metal sites using $\mathrm{H}_{2}$ or $\mathrm{CO}$ as the probe molecule [31]. Thus, when combined with data regarding the progress of catalytic reactions, adsorption microcalorimetry allows more in-depth knowledge of the relationship between catalytic reactivity and active sites. Furthermore, a direct relationship between binding strength and reactivity can be established by using reactants, intermediate and products as probe molecules. Finally, the reaction energetics as determined by microcalorimetry allow elucidation of the overall catalytic process.

In the following sections, studies regarding the three microcalorimetric applications noted above are described, and an overview of the relationship between adsorption/reaction energetics and reactivity on supported catalysts is provided.

\subsection{Correlating the binding strength of active sites with reactivity}

Specific reaction rates, or turnover frequency (TOF) values, that are calculated according to the number of active sites are often used to compare the reactivities of different catalysts [32]. However, such comparisons should also take into consideration the binding strengths of such sites, because both activity and selectivity often change with variations in the strength. As an example, Dumesic and coworkers [33] studied changes in the reactivity of a sulfated zirconia catalyst during $n$-butane isomerization as the interaction strengths of acidic sites were varied by selective poisoning with $\mathrm{NH}_{3}$. The acidic sites with the strongest interactions, having $\mathrm{NH}_{3}$ adsorption heats of $145-165 \mathrm{~kJ} / \mathrm{mol}$, were found to contribute to the high initial activity of the catalysts, but were deactivated rapidly under reaction conditions. As compared with the strongest acidic sites, the intermediate acidic sites with $\mathrm{NH}_{3}$ adsorption heats of $125-145 \mathrm{~kJ} / \mathrm{mol}$ were less active, but deactivated more slowly. The sites with lower heat outputs exhibited low activity and rapid deactivation. Sites having different binding strengths also exhibited different selectivities: the strongest acidic sites showed higher selectivity for isobutane as compared with the weaker sites (those with heats from 120 to $125 \mathrm{~kJ} / \mathrm{mol}$ ) [33]. These results highlight the importance of correlating the interaction strengths of active sites with reactivity.

\subsubsection{Relationship between the binding strengths of acid-base sites and reactivity}

Attempts have been made to associate Brönsted or Lewis sites with different ranges of the heat of adsorption of $\mathrm{NH}_{3}$ or pyridine, using microcalorimetry $[7,34]$. Such correlations suggest the possibility of directly comparing the reactivities of acidic sites on different types of catalysts. The relationship between the TOF during methanol dehydration to dimethyl ether (DME) and the initial heat of $\mathrm{NH}_{3}$ adsorption was established in the case of tungsten Keggin heteropoly acids (HPA) and HZSM-5 zeolites (Fig. 3) [35]. Good correlations were found for both the HPA and HZSM-5, indicating that the methanol dehydration TOF was primarily governed by the binding strength of the acidic sites and that methanol was dehydrated by the same mechanism on both catalysts. The effects of acid-base properties on the gas phase dehydration of glycerol over zirconia and titania-based catalysts were also studied by microcalorimetry $[36,37]$. Here the reaction selectivity was determined to be primarily dependent on the ratio of acidic to basic sites. As shown in Fig. 4, increases in the ratio of the adsorption of $\mathrm{NH}_{3}$ to that of $\mathrm{SO}_{2}$ increased the selectivity for acrolein, although the selectivity plateaued at a ratio of 6 . 


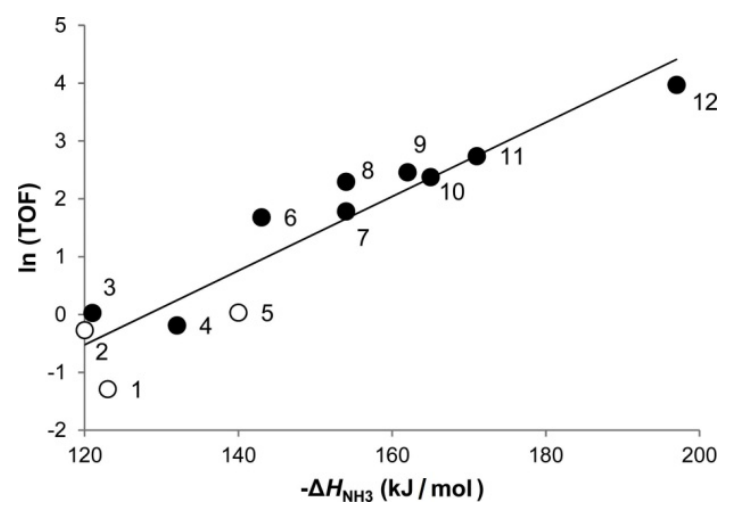

Fig. 3. Plot of $\ln (\mathrm{TOF})$ for methanol dehydration (TOF expressed in units of $\mathrm{h}^{-1}$ ) on tungsten heteropoly acid catalysts $(\bullet)$ and HZSM-5 zeolites ( 0 ) versus the initial heat of $\mathrm{NH}_{3}$ adsorption for 12 samples having different compositions [35].

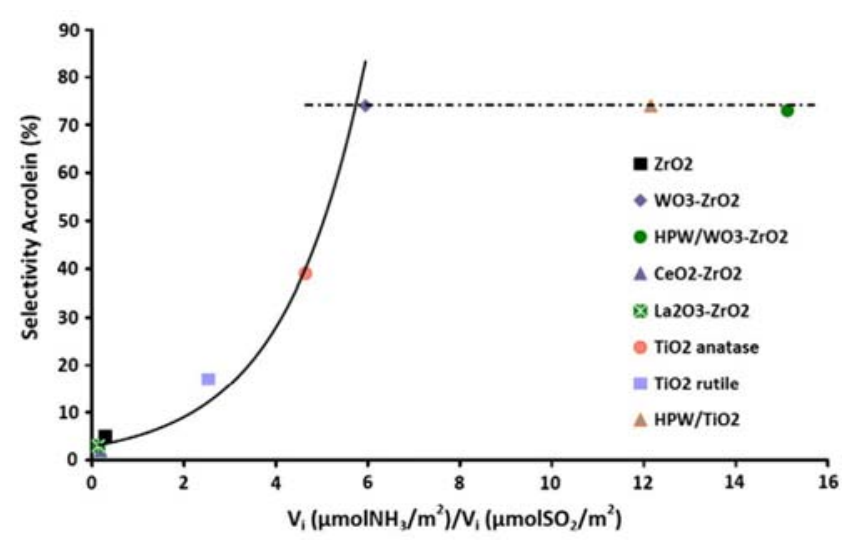

Fig. 4. Selectivity for acrolein as a function of the $\mathrm{Vi}\left(\mu \mathrm{mol} \mathrm{NH_{3 }} \mathrm{m}^{-2}\right) / \mathrm{Vi}$ $\left(\mu \mathrm{mol} \mathrm{SO}{ }_{2} \mathrm{~m}^{-2}\right)$ ratio [36].

The addition of doping elements is widely used as a means of tuning the acid-base properties of oxides and zeolites, and $\mathrm{NH}_{3}$ adsorption microcalorimetry has been employed to study Al-promoted zirconia catalysts intended for the isomerization of $n$-butane [38]. The number of acidic sites with intermediate acid strengths $\left(\mathrm{NH}_{3}\right.$ adsorption heats from 125 and 140 $\mathrm{kJ} / \mathrm{mol}$ ) that were effective for the $n$-butane isomerization [39] was greatly increased in the Al-promoted catalysts, resulting in remarkable levels of activity and stability. Similarly, the addition of $\mathrm{Al}$ and $\mathrm{Ga}$ to tungstated zirconia increased the number of acidic sites with $\mathrm{NH}_{3}$ adsorption heats in the range of 199 to $237 \mathrm{~kJ} / \mathrm{mol}$ significantly, which in turn contributed to enhanced activity and selectivity for $n$-pentane isomerization [40]. The acid-base properties of beta-zeolite-supported tungsten catalysts and the relationship between these properties and hydrocracking functionality have also been studied [41], and a correlation between acid strength and activity during the hydrocracking of cumene (HCK) has been reported. As shown in Fig. 5, the acidic sites with initial $\mathrm{NH}_{3}$ adsorption heats greater than or equal to $100 \mathrm{~kJ} / \mathrm{mol}$ were responsible for the HCK rates over these catalysts. The activity during glycerol dehydration to acrolein on silica-supported niobia catalysts has also been correlated with acid strength [42]. In this work, a linear relationship between the acrolein formation rate and the heat of

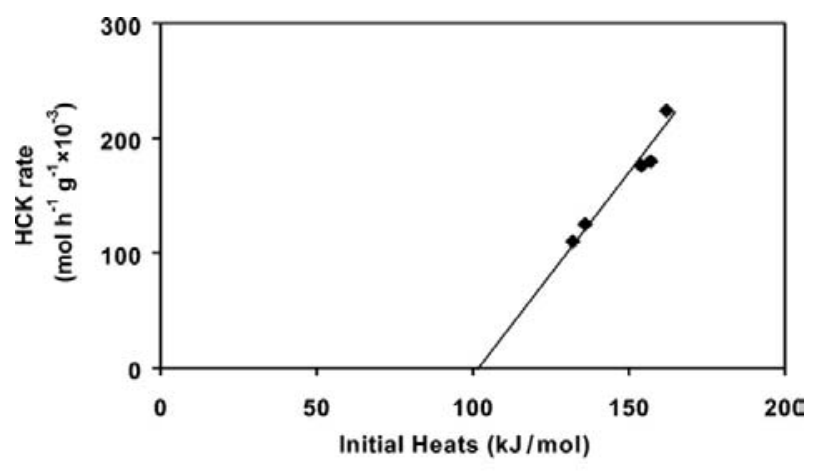

Fig. 5. Correlation of the initial heats of adsorption of $\mathrm{NH}_{3}$ with cumene hydrocracking rates over tungsten sulfide catalysts supported on H- $\beta$-zeolite [41].

$\mathrm{NH}_{3}$ adsorption was found, suggesting that the enhanced acrolein formation rate could be attributed to higher acid strength.

$\mathrm{NH}_{3}$ adsorption microcalorimetry has been used to probe the strengths of the acidic sites on $\mathrm{WO}_{x} / \mathrm{ZrO}_{2}$ with increasing $\mathrm{WO}_{3}$ loadings [43]. The quantity of Brönsted acid sites with $\mathrm{NH}_{3}$ adsorption heats ranging from 90 to $130 \mathrm{~kJ} / \mathrm{mol}$ was found to increase with $\mathrm{WO}_{3}$ loading. Increased amounts of Brönsted acidic sites on the catalyst loaded with the highest amount of $\mathrm{WO}_{3}$ led to the best catalytic performance during the hydrolysis of cellobiose. The relationship between acid-base properties and reactivity during fructose conversion to 5-hydroxymethylfurfural (5-HMF) on tungstated zirconia catalysts with different $\mathrm{WO}_{3}$ loadings is plotted in Fig. 6 [44]. The selectivity for 5-HMF was highly dependent on the ratio of $\mathrm{SO}_{2}$ to $\mathrm{NH}_{3}$ adsorption (Fig. 6(a)), while the presence of acidic sites with $\mathrm{NH}_{3}$ adsorption heats from 100 to $150 \mathrm{~kJ} / \mathrm{mol}$ was evidently responsible for the conversion to 5-HMF (Fig. 6(b)).

Catalyst supports having different structures and acid-base properties often alter the performance of the catalyst. Shen and coworkers studied the effects of supports with varying acid-base properties on the hydrogenations of aromatic rings [45], lauronitrile [46] and pyridine [47] over supported nickel catalysts. In the case of toluene, the aromatic ring can be considered as a Lewis base because of the high electron density in this structure. Thus, both the initial heat of adsorption and the saturation uptake of toluene were higher on $\mathrm{Ni} / \mathrm{Al}_{2} \mathrm{O}_{3}$ due to the acidity of the support, leading to enhanced hydrogenation of both toluene and phenol $[45,48]$. In the case of the hydrogenation of lauronitrile, the basicity of the support was found to govern the selectivity for primary amines, while the surface acidity was responsible for the degree of conversion. Ni/MgAlO exhibited a significant number of both acidic and basic sites with intermediate strengths, which led to both enhanced conversion of lauronitrile and primary amine selectively [46]. The increased electron density of Ni resulting from electron transfer from the basic support (MgO) reduced the $\mathrm{Ni}-\mathrm{H}$ bond strength, and so decreased the hydrogenation of pyridine. In contrast, the hydrogenation of pyridine was accelerated when using an acidic support $\left(\mathrm{Al}_{2} \mathrm{O}_{3}\right)$ because of the enhanced adsorptions of $\mathrm{H}_{2}$ and pyridine due to the presence of the electron-deficient Ni on the catalyst surface [47].

The formation of mixed oxides is a common strategy used to 

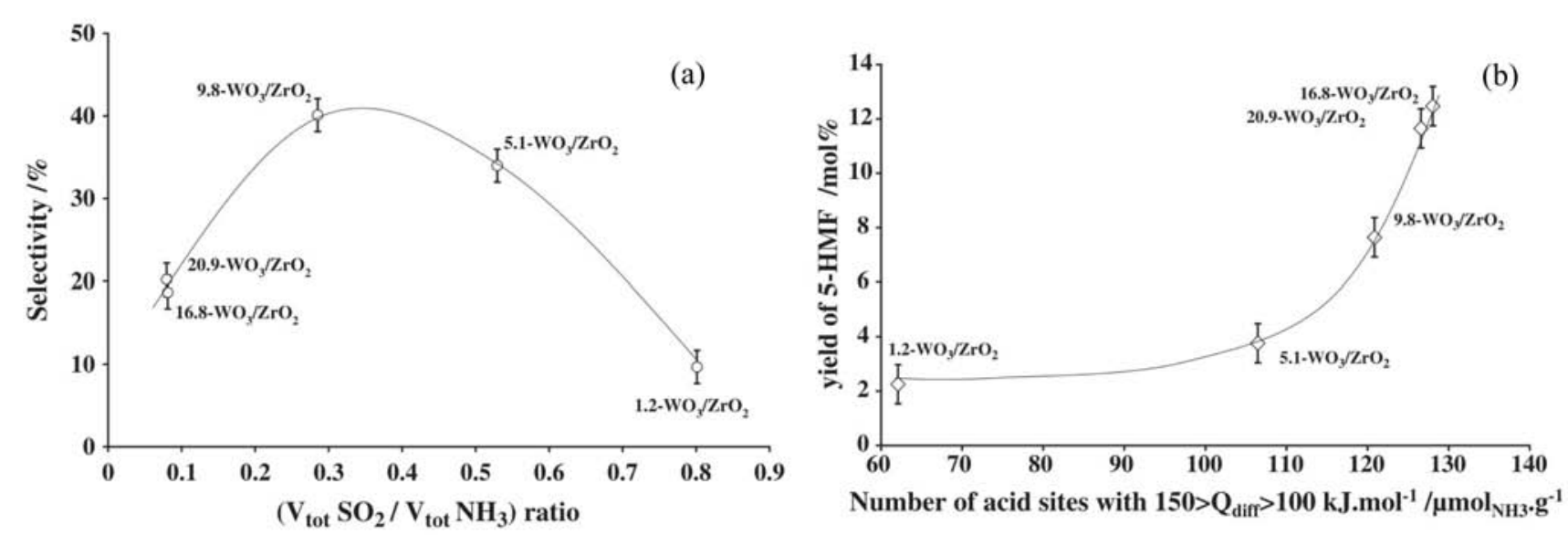

Fig. 6. (a) Selectivity for 5-HMF as a function of the ratio of basic to acidic sites, and (b) the correlation between the yield of 5 -HMF and the number of medium strength acidic sites [44].

tune the acid-base properties and reactivities of the parent oxides. The weaker acid strength of $\mathrm{V}$-Ag-O catalysts compared to that of $\mathrm{VO}_{x}$ is one important reason for the enhanced performance of the former materials during the selective oxidation of toluene to benzaldehyde and benzoic acid [49]. The reactivities of acidic sites having different $\mathrm{NH}_{3}$ adsorption strengths during glycerol dehydration on niobium-zirconium mixed oxide catalysts have also been studied by microcalorimetry [50]. Two types of acidic sites were identified on these catalysts: those with adsorption heat releases from 80 to $120 \mathrm{~kJ} / \mathrm{mol}$ (denoted as weak acidic sites) and those with heat releases below $80 \mathrm{~kJ} / \mathrm{mol}$, termed very weak sites. The rates of glycerol dehydration at the two kinds of acidic sites were calculated based on the relative quantities of these sites, and the reactivity of the weak acidic sites was determined to be more than ten times that of the very weak sites. In addition, microcalorimetry was applied to the analysis of MgNiAl mixed oxides used for the conversion of 4-methylpentan-2-ol [51], and the results indicated that the product selectivity was dependent on both acidic and basic sites with heats of adsorption in the range of 110-150 kJ/mol. The effects of acid-base properties on the selective reduction of $\mathrm{NO}_{x}$ with $n$-decane over $\mathrm{ZrO}_{2}$ based mixed oxides were examined using $\mathrm{NH}_{3}$ and $\mathrm{SO}_{2}$ adsorption microcalorimetry [52]. In this work, the relationship between the reactivity and the acid strength indicated that moderately acidic sites (with $\mathrm{NH}_{3}$ adsorption heats in the range of 100-150 $\mathrm{kJ} / \mathrm{mol}$ ) favored $\mathrm{NO}_{x}$ conversion and selectivity for $\mathrm{N}_{2}$, while strongly acidic sites promoted the oxidation of hydrocarbons, after which these compounds were no longer able to act as reducing agents.

The properties of both acidic and basic sites are often governed by the chemical composition of the material. Microcalorimetric studies have clearly indicated that the steam dealumination of faujasites and mordenite zeolites produce new, stronger acidic sites that enhance catalytic activity during the conversions of hydrocarbons [53,54]. Studies using $\mathrm{NH}_{3}$ adsorption microcalorimetry have shown that increases in the crystallinity of zeolite-based materials, as determined by X-ray diffraction (XRD), are associated with increased quantities of strong Brönsted acid sites with $\mathrm{NH}_{3}$ adsorption heats from 120 to $140 \mathrm{~kJ} / \mathrm{mol}$ [55]. A significant correlation between the number of strong Brönsted acid sites and catalytic activity during $n$-hexane cracking over zeolite-based materials was also identified (Fig. 7). The relationship between the acid-base properties of calcium phosphate catalysts with different $\mathrm{Ca} / \mathrm{P}$ ratios and glycerol dehydration has also been studied [56], and the product selectivity has been found to be highly dependent on the strengths and numbers of both acidic and basic sites. In these studies, acrolein selectively was improved by increasing the quantity of acidic sites while suppressing basic sites. In contrast, the yield of acetol was increased when both the quantity and strength of the acidic sites were reduced.

\subsubsection{Relationship between the strengths of metal sites and reactivity}

Microcalorimetric assessments of metal active sites, although not employed as often as for acid-base sites, have been attempted as an approach to correlating catalytic reactivity to catalyst structure. Dumesic and coworkers [57-59] investigated the Pt sites of both Pt and PtSn-based catalysts for isobutene dehydrogenation. The addition of $\mathrm{Sn}$ to $\mathrm{Pt}$ was found to increase the selectivity for isobutylene while inhibiting the coking reaction, and the microcalorimetric results suggested that

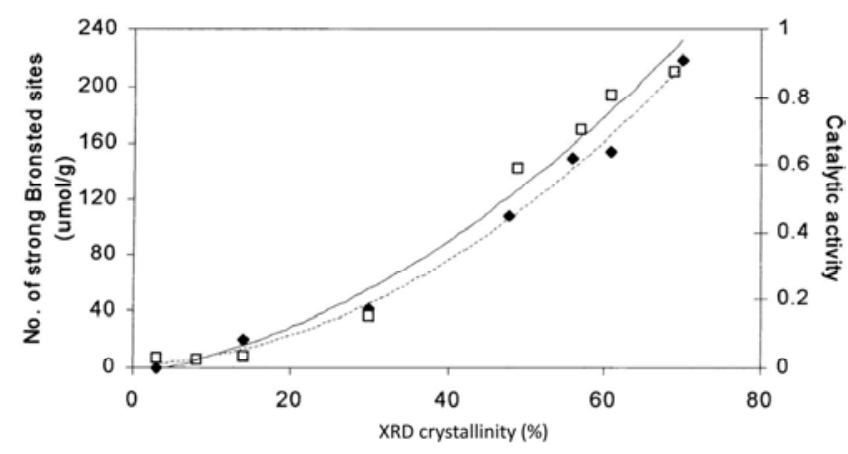

Fig. 7. Plots showing the quantities of strong Brönsted acid sites ( $\bullet$ ) and the catalytic activity during $n$-hexane cracking ( $\square$ ) as functions of the percentage crystallinity of ZSM-5-based samples as determined by XRD [55]. 
Sn suppressed the number of Pt sites capable of strongly adsorbing hydrogen or CO. Nevertheless, this decrease in strong Pt sites was not the sole reason for the selectivity, because strong adsorption sites were also present on a Pt/Sn catalyst that similarly exhibited high selectivity. In fact, the primary cause of the high selectivity was determined to be the suppression of the formation of highly dehydrogenated species due to the decreasing size of surface Pt ensembles with the addition of Sn [57]. Additional studies of the effects of K on Pt and PtSn catalysts during isobutane dehydrogenation showed that the addition of $\mathrm{K}$ did not significantly alter the interaction strengths between $\mathrm{H}_{2}$ and $\mathrm{CO}$ and the supported metal. In contrast, $\mathrm{K}$ increased the sites available for hydrogen adsorption while decreasing $\mathrm{CO}$ adsorption. The increased hydrogen adsorption sites favored the removal of hydrogen from adsorbed isobutane and also stabilized adsorbed isobutene molecules, improving the dehydrogenation rate over the $\mathrm{Pt} / \mathrm{Sn} / \mathrm{K}$ catalyst [58]. The effects of other alkali metals, such as $\mathrm{Na}, \mathrm{Rb}$ and $\mathrm{Cs}$, on isobutane dehydrogenation were also studied. A decrease in the CO adsorption of the $\mathrm{Pt} / \mathrm{Sn}$ caused by the presence of $\mathrm{Na}$ and $\mathrm{Cs}$ salts suggested that these alkali species were possibly combining with $\mathrm{Sn}$ in the Pt/Sn particles, thus decreasing the sizes of Pt ensembles, which in turn enhanced the selectivity for isobutane dehydrogenation [59]. This same group also compared the Pt sites for n-hexane conversion on silica- and L-zeolite-supported Pt catalysts [60]. Although freshly reduced samples exhibited the same initial heats of CO adsorption, the number of sites interacting strongly with $\mathrm{CO}$ were decreased in the case of the $\mathrm{Pt} / \mathrm{SiO}_{2}$ but remained constant on the $\mathrm{Pt} / \mathrm{K}(\mathrm{Ba})$-L during $n$-hexane conversion. The presence of strong adsorption sites during the reaction was reported to contribute to the higher dehydrocyclization activity over the Pt/K(Ba)-L. d'Alnoncourt et al. [61] correlated the initial heats of $\mathrm{CO}$ adsorption with activities during methanol synthesis over various Cu-based catalysts. As shown in Fig. 8, the highest CO adsorption heat of $81 \mathrm{~kJ} / \mathrm{mol}$ was obtained from $\mathrm{Cu} / \mathrm{Al}_{2} \mathrm{O}_{3}$, even though this material had the lowest activity during methanol synthesis. The addition of $\mathrm{ZnO}$ to the $\mathrm{Cu} / \mathrm{Al}_{2} \mathrm{O}_{3}$ covered the $\mathrm{Cu}$ sites with $\mathrm{ZnO}_{x}$ because of the strong metal-support interactions, lowering the interaction strength between $\mathrm{CO}$ and $\mathrm{Cu}$

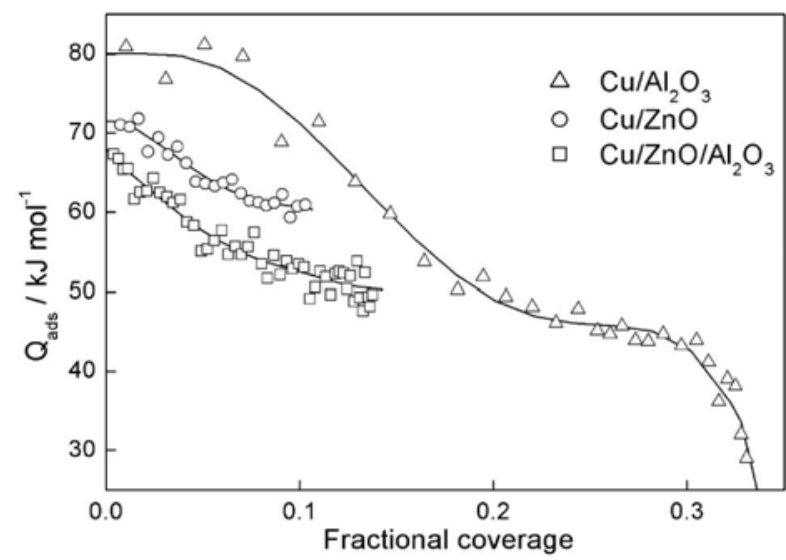

Fig. 8. Differential heats of adsorption of $\mathrm{CO}$ on $\mathrm{Cu}$ catalysts at $300 \mathrm{~K}$ [61]. sites. These changes at the $\mathrm{Cu}$ sites resulted in the best catalytic performance for methanol synthesis, in conjunction with the lowest initial heat of adsorption of $67 \mathrm{~kJ} / \mathrm{mol}$. The surface sites on $\mathrm{Ru} / \mathrm{C}$ catalysts have been studied by microcalorimetry and correlated to the reactivity during the Fischer-Tropsch (F-T) reaction [62,63]. Residual chlorine, produced from the $\mathrm{RuCl}_{3}$ precursor during preparation of the catalyst, was found to attach strongly to the $\mathrm{Ru}$ particles, covering the $\mathrm{Ru}$ active sites and in turn lowering the $\mathrm{CO}$ adsorption energetics [62]. In contrast, the addition of $\mathrm{Cs}$ to $\mathrm{Ru} / \mathrm{C}$ increased the interaction strength of $\mathrm{CO}$ with $\mathrm{Ru}$ sites. The higher $\mathrm{CO}$ adsorption energetics increased the CO coverage and likely inhibited the adsorption of $\mathrm{H}_{2}$, leading to improved olefin selectivity and long-chain hydrocarbon production from the F-T reaction [63].

The performance of a catalyst is highly dependent on both its nanostructure (that is, its size and shape) and its composition. However, it is common that neither the structure nor the composition is uniform on the surfaces of heterogeneous catalysts. As an example, metal-based catalysts typically have a wide particle size distribution, and the densities of the coordinatively-unsaturated sites at the corners and edges of metal particles increase with decreasing particle size [64]. The binding strengths at these corner or edge sites are significantly higher than those at terraces or smooth surfaces [65]. As a result, the energetic distribution of the active sites on supported catalysts is heterogeneous. For this reason, TOF values calculated based on all active sites are often predicated on the erroneous assumption that all catalyst components contribute to the activity equally. The quantification of active sites with adsorption microcalorimetry allows the possibility of determining the most active sites in a given reaction, and therefore can provide direction for the improvement of catalytic performance. Nevertheless, to achieve the optimum effectiveness in such studies, adsorption microcalorimetry must be used in combination with other techniques that probe the nature of the adsorbed species [66]. One example is the use of Fourier Transform Infrared (FT-IR) spectroscopy to identify which ranges within the acid strength distribution correspond to Lewis versus Brönsted sites in studies of acid-base properties [35,67]. In investigations of metal catalysts, IR data can discriminate the CO adsorption heat values that correspond to linear, bridged and multi-bonded sites [68,69]. Furthermore, a combination of density functional theory (DFT) calculations and microcalorimetric measurements can provide a detailed description of the relationship between chemical bonding and the energetics of acidic sites [70] and metal sites [71] on supported catalysts.

\subsection{Correlating the bond strengths of reactants, intermediates and products with reactivity}

Although the strengths and quantities of acidic, basic and metal sites can account for the reactivity of a catalyst, a more direct relationship with reactivity can be established when using reactants, products and possible intermediates as probe molecules.

\subsubsection{Correlating the bond strengths of reactants with}




\section{reactivity}

Generally, the catalytic cycle includes at least three steps. Firstly, the adsorption of the reactants onto the surface of a catalyst triggers the catalytic reaction, after which the adsorbed species react via the possible intermediates to the final products. Finally, the desorption of the product from the surface of the catalyst signals the completion of the catalytic cycle. Considering that the adsorption of reactants is the starting point of the catalytic reaction, it is possible to understand the reactivity according to the adsorption energetics of reactants. As an example, the addition of Sn to Pt-based catalysts that convert ethanol and acetic acid to $\mathrm{CO}$ and $\mathrm{CH}_{4}$ significantly inhibits cleavage of the $\mathrm{C}-\mathrm{C}$ bonds in the reactants [72]. Microcalorimetric data for these reactions indicate that Sn decreases the strength of the interaction between ethanol or acetic acid and the Pt catalysts, suppressing the decomposition of reactants. Microcalorimetric assessments of the adsorption of reactants was also applied to assist in understanding the high selectivity for $\mathrm{C}_{2} \mathrm{H}_{4}$ during the 1,2-dichloroethane hydrodechlorination reaction over a $\mathrm{Pt} / \mathrm{SiO}_{2}$ catalyst modified with $\mathrm{Cu}$ [73]. $\mathrm{Cu}$ was found to decrease the adsorption energetics of the 1,2-dichloroethane significantly while only moderately affecting the heat of $\mathrm{H}_{2}$ adsorption on the Pt catalyst, resulting in the competitive adsorption of both reactants and subsequent reaction on the bimetallic material. In contrast, a change in the adsorption energetics of the reactants suppressed not only the deactivation induced by the strongly adsorbed 1,2-dichloroethane, but also the over-hydrogenation of intermediates by $\mathrm{H}_{2}$, leading to improved selectivity for ethylene. Wrabetz et al. [74] conducted microcalorimetric studies of the skeletal isomerization of $n$-butane on sulfated zirconia catalysts. At least two different sites for $n$-butane adsorption, with adsorption heat releases of 50-60 and $40 \mathrm{~kJ} / \mathrm{mol}$, were identified on the activated sulfated zirconia. Following a reaction induction period, the $50-60 \mathrm{~kJ} / \mathrm{mol}$ sites disappeared, suggesting that these sites activated the isomerization reaction. Amakawa et al. studied the metathesis of propene to ethene and 2-butene over $\mathrm{MoO}_{x} / \mathrm{SBA}-15$ catalysts with different Mo loadings. In this work, the numbers and strengths of reactant adsorption sites could be correlated to the concentrations of the active carbene $(\mathrm{Mo}=\mathrm{CHR})$ species that catalyzed the metathesis reaction [75]. In addition, microcalorimetry was used to examine the conversion of $\mathrm{CO}_{2}$ to various fuels over $\mathrm{FeO}_{x} /$ carbon nanotube-based electrocatalysts [76]. Two types of $\mathrm{CO}_{2}$ chemisorption sites having different strengths were found; irreversible sites with an adsorption heat of $280 \mathrm{~kJ} / \mathrm{mol}$ and reversible sites with heats of $120 \mathrm{~kJ} / \mathrm{mol}$. Based on their correlation with electrocatalytic performance, the reversible chemisorbing sites were confirmed to play a more important role in the reaction. Microcalorimetry was also used to study $\mathrm{CO}_{2}$ photoreduction on highly dispersed $\mathrm{CeO}_{2} / \mathrm{TiO}_{2}$ catalysts [77]. Weak interactions between $\mathrm{TiO}_{2}$ and $\mathrm{CO}_{2}$ molecules were reported to impede $\mathrm{CO}_{2}$ photoreduction, while the addition of $\mathrm{CeO}_{2}$ (containing $\mathrm{Ce}^{3+}$ ) to $\mathrm{TiO}_{2}$ increased the bonding strength of $\mathrm{CO}_{2}$ molecules to the catalyst surface as b- $\mathrm{CO}_{3}{ }^{2-}$ and b-HCO ${ }^{3-}$ species were formed. Because these surface species were responsible for the production of $\mathrm{CO}^{2-}$, the intermediate in the
$\mathrm{CO}_{2}$ photocatalytic reduction, these changes resulted in improved photoreduction performance.

\subsubsection{Correlating the bond strengths of products with reactivity}

The facile desorption of products from the catalyst surface is also very important, because strongly adsorbed species have a tendency to mask active sites. An investigation comparing MoP and $\mathrm{Mo}_{2} \mathrm{~N}$ during hydrazine decomposition used the product $\mathrm{NH}_{3}$ as the probe molecule [78], and determined that $\mathrm{Mo}_{2} \mathrm{~N}$ exhibited much higher adsorption energetics for $\mathrm{NH}_{3}$ than MoP. This difference led to significantly lower catalytic stability in the case of the $\mathrm{Mo}_{2} \mathrm{~N}$ because the strongly adsorbed $\mathrm{NH}_{3}$ covered the active sites. The adsorption energetics of oxygen and NO on supported $\mathrm{Pt} / \mathrm{Al}_{2} \mathrm{O}_{3}$ catalysts active for $\mathrm{NO}_{x}$ oxidation and $\mathrm{NO}_{2}$ dissociation have been measured by microcalorimetry [79]. The higher adsorption heat of oxygen was considered to be responsible for the high light-off temperature during $\mathrm{NO}_{2}$ dissociation, because oxygen desorption was the rate-determining step. Shen and coworkers [80] studied the effect of $\mathrm{K}_{2} \mathrm{CO}_{3}$ on the acetonitrile hydrogenation reaction on $\mathrm{Ni} / \mathrm{MgAlO}$. The adsorption of ethylamine, the product of the hydrogenation of acetonitrile, produced an initial heat of 170 $\mathrm{kJ} / \mathrm{mol}$ on supported $\mathrm{Ni}$, while the addition of $\mathrm{K}_{2} \mathrm{CO}_{3}$ lowered this value to $126 \mathrm{~kJ} / \mathrm{mol}$. The improved selectivity for the primary amine over the $\mathrm{K}_{2} \mathrm{CO}_{3}-\mathrm{Ni} / \mathrm{MgAlO}$ was attributed to the ready desorption of ethylamine.

\subsubsection{Correlating the bond strengths of intermediates with reactivity}

In many cases, probe molecules can be employed if the adsorbed states of these molecules are considered to be related to important intermediates in the catalytic reaction. One example is ethanol steam reforming for hydrogen production, in which acetaldehyde is believed to be the intermediate species. The adsorption energetics of the reactant (ethanol) and intermediate (acetaldehyde) have been measured by microcalorimetry to understand the reactivity of ethanol steam reforming on supported cobalt catalysts [81]. Ethanol and acetaldehyde have been reported to have similar initial adsorption heats on a fresh $\mathrm{Co} / \mathrm{ZnO}$ catalyst. The carbon deposition resulting from the reaction lowers the quantity of the strongest sites for ethanol adsorption, while these sites are not affected by the adsorption of acetaldehyde. However, strongly adsorbed acetaldehyde covers the active sites, lowering the catalytic performance during the ethanol steam reforming reaction. Shen and coworkers [82] studied F-T synthesis over a highly loaded $\mathrm{Co}-\mathrm{ZrO}_{2} / \mathrm{SiO}_{2}$ catalyst via microcalorimetry, using the reactants $\mathrm{H}_{2}$ and $\mathrm{CO}$, and the possible intermediate $\mathrm{C}_{2} \mathrm{H}_{4}$ as probe molecules. In contrast to the dissociative species formed on Co catalysts, molecularly adsorbed ethylene was identified on CO-preadsorbed and $\mathrm{ZrO}_{2}$-promoted $80 \% \mathrm{Co} / \mathrm{SiO}_{2}$ catalysts (Fig. 9). The presence of $\mathrm{ZrO}_{2}$ on the $\mathrm{CO}$-preadsorbed Co material increased the bonding strength of the molecularly adsorbed ethylene from 37 to $140 \mathrm{~kJ} / \mathrm{mol}$ and elevated the $\mathrm{C}_{2} \mathrm{H}_{4}$ uptake from 20 to 40 $\mu \mathrm{mol} / \mathrm{g}$. The improved adsorption strength and uptake were held to be responsible for the high activity of an $80 \% \mathrm{Co}-8 \% \mathrm{ZrO}_{2} / \mathrm{SiO}_{2}$ catalyst for $\mathrm{CO}$ hydrogenation to heavy 

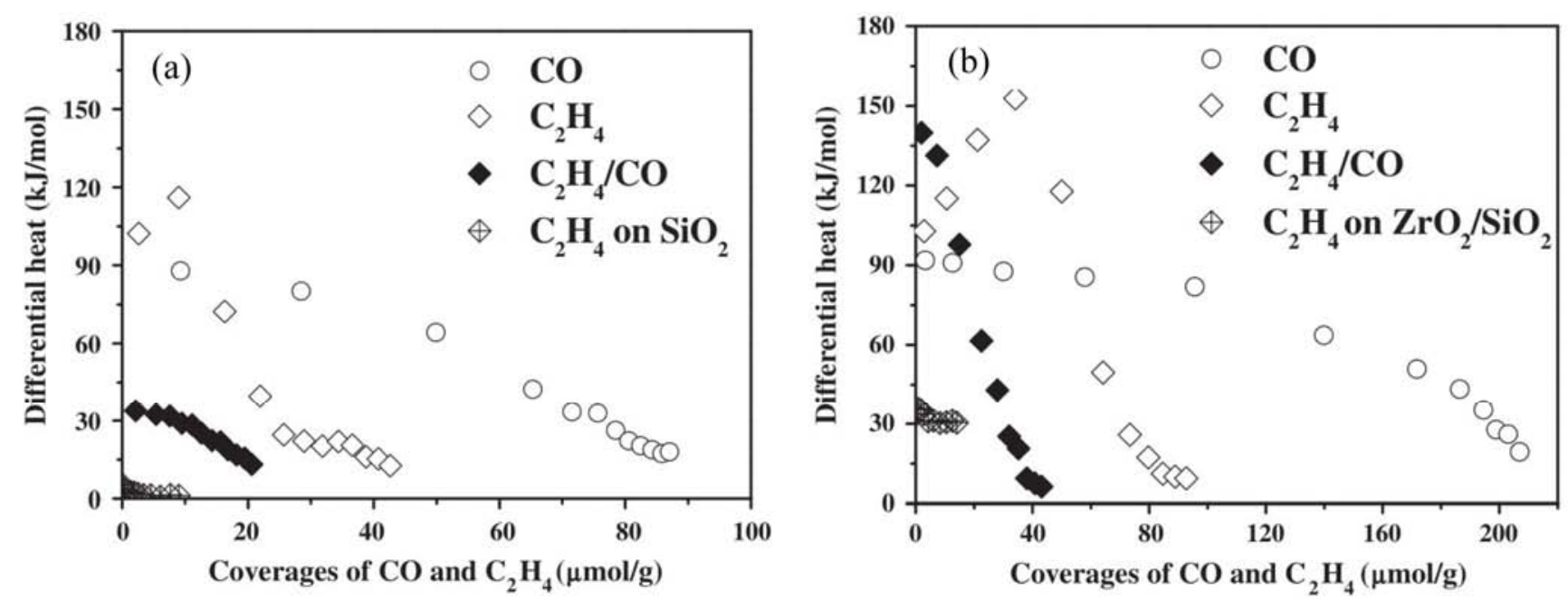

Fig. 9. Differential heats vs. coverage for $\mathrm{C}_{2} \mathrm{H}_{4}$ adsorption onto (a) clean, CO-preadsorbed $\left(\mathrm{C}_{2} \mathrm{H}_{4} / \mathrm{CO}\right) 80 \% \mathrm{Co} / \mathrm{SiO}$, and (b) $80 \% \mathrm{Co}-8 \% \mathrm{ZrO}{ }_{2} / \mathrm{SiO}{ }_{2}$ catalysts [82].
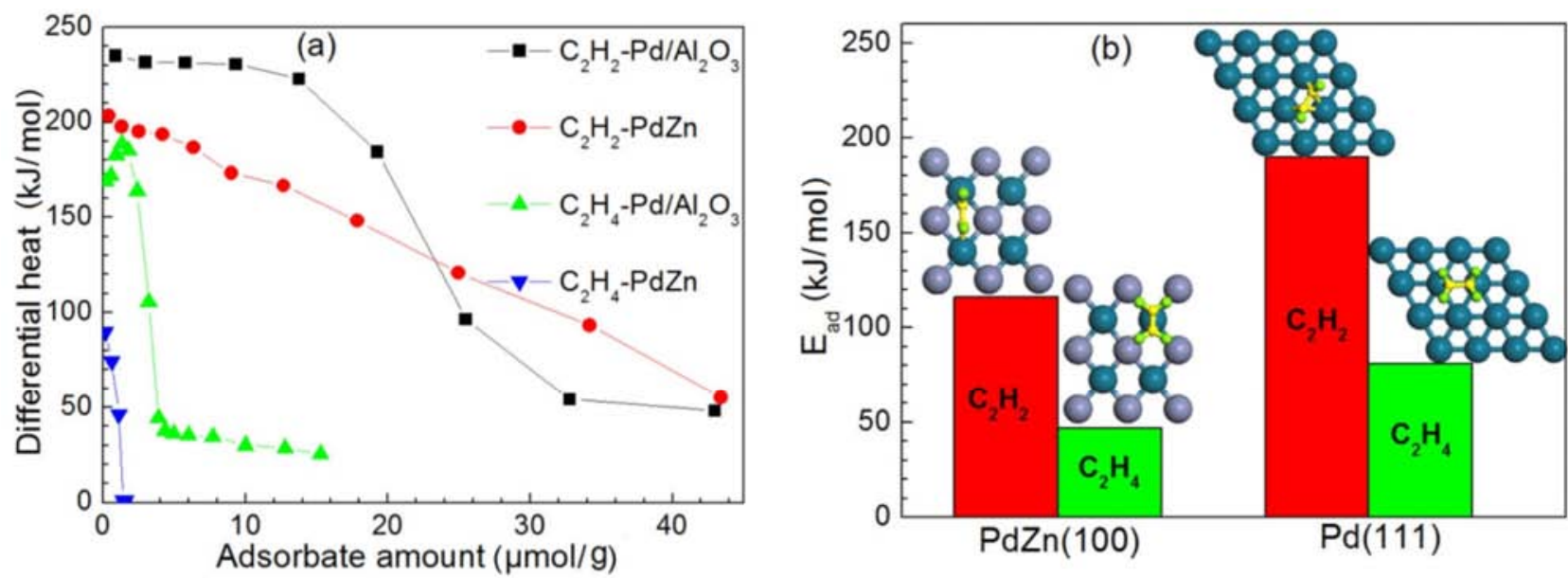

Fig. 10. (a) Microcalorimetry data for acetylene and ethylene adsorptions on $\mathrm{PdZn}$ and $\mathrm{Pd} / \mathrm{Al}_{2} \mathrm{O}_{3}$ catalysts, and (b) DFT modeling of these adsorptions on PdZn(100) or Pd(111) surfaces [85].

hydrocarbons.

Zhang and coworkers studied the effects of $\mathrm{Au}$ [83], $\mathrm{Ag}$ [84] and $\mathrm{Zn} \mathrm{[85]} \mathrm{on} \mathrm{Pd}$ catalysts for the chemoselective semi-hydrogenation of acetylene. The results of structural characterization indicated that isolated Pd sites were generated upon the formation of PdAu, PdAg and PdZn alloys. Changes in the adsorption strengths of these materials were studied by microcalorimetric measurements and DFT calculations. As shown in Fig. 10, both acetylene and ethylene adsorption on the monometallic Pd catalyst produced high adsorption energetics. Acetylene adsorbed in the $\sigma$-bonding mode on PdZn led to only a slight decrease in the adsorption strength, suggesting that the activation of reactants was not affected by the formation of the PdZn alloy. In contrast, the weak $\pi$-bonding of ethylene on the PdZn lowered the adsorption heat significantly, restricting further hydrogenation of the ethylene and leading to high selectivity for ethylene from acetylene [85].

Adsorption microcalorimetry using reactants, products and possible intermediates as probe molecules can provide important information concerning the interaction strengths of these species with the catalyst surface, and possibly elucidate the manner in which the catalyst binds the reactants and guides them through possible intermediates to the final products. Compared with simple probe molecules such as $\mathrm{NH}_{3}$ or $\mathrm{CO}$, the reactants, products and intermediates are usually more complex, and the strengths of their interactions with active sites are not easily derived from methods such as TPD or isothermal adsorption, since these molecules often decompose before desorbing. Microcalorimetry provides a reliable means of obtaining such adsorption energetics. Nevertheless, a better understanding of the nature of the interactions is provided by combining the results of other characterization techniques that also probe the nature of the surface-adsorbed species [77,80-82]. Furthermore, DFT theoretical analyses can be used as a complementary method to assist in interpreting the catalytic process through examining the various elementary steps [85].

\subsection{Correlating the reaction energetics with reactivity}

In addition to the energetics of adsorption, the other steps in 
the catalytic cycle also proceed with the evolution of heat. Thus, energetic measurements over the entire catalytic cycle can provide an improved understand of the catalytic reaction from the energetic point of view. Nevertheless, the energetics of the overall catalytic reaction are more complex, because the evolved heat originates from the three steps in the catalytic cycle, and so it is important to distinguish the energetic contributions of the various chemical events. To accomplish this goal, as much energetic information as possible should be obtained to assist in understanding the reaction energetics.

\subsubsection{Reaction energetics measured by in situ pulse microcalorimetry}

Yeung et al. [86] found that noble metals supported on $\left(\mathrm{NM}-\mathrm{on}-\mathrm{CeO}_{2}\right)$ or encapsulated by $\mathrm{CeO}_{2}\left(\mathrm{NM}-\mathrm{in}-\mathrm{CeO}_{2}\right)$ generated different structure-activity relationships during the preferential oxidation of CO (PROX). Comparative studies of the CO oxidation process were performed on these materials using in situ pulse microcalorimetry [26]. The resulting adsorption heats indicated that the $\mathrm{Ir}-\mathrm{in}-\mathrm{CeO}_{2}$ exhibited lower adsorption strengths for the reactants ( $\mathrm{CO}$ and $\mathrm{O}_{2}$ ), although this material showed the same binding strength for the product $\left(\mathrm{CO}_{2}\right)$ as the Ir-on- $\mathrm{CeO}_{2}$. Based on the standard reaction enthalpy of $\mathrm{CO}$ oxidation [87], the reaction energetics of $\mathrm{CO}$ with adsorbed oxygen species to form $\mathrm{CO}_{2}$ and carbonates on the Ir-in-CeO $\mathrm{C}_{2}$ were calculated as 110 and $252 \mathrm{~kJ} / \mathrm{mol}$, respectively. Finally, measurements of adsorption/reaction energetics were conducted by successively sending pulses of the $\mathrm{CO}+\mathrm{O}_{2}$ mixture (at a 2:1 ratio) to the Ir-in- $\mathrm{CeO}_{2}$ (Fig. 11(a)). Despite significant consumption of $\mathrm{CO}$ and $\mathrm{O}_{2}$ over the first four pulses, no production of $\mathrm{CO}_{2}$ was observed. The measured heat was close to the reaction energetics of $\mathrm{CO}$ with adsorbed oxygen species, suggesting that carbonates were initially formed during this stage. Further pulses of $\mathrm{CO}+\mathrm{O}_{2}$ gradually generated $\mathrm{CO}_{2}$ with the highest conversion of $6 \%$ at the eighth pulse, accompanied by a decrease in the heat release to $210 \mathrm{~kJ} / \mathrm{mol}$ due to the lower reaction energetics of $\mathrm{CO}_{2}$ production. More $\mathrm{CO}_{2}$ was produced over the Ir-on- $\mathrm{CeO}_{2}$, and the amounts generated were found to increase with the number of pulses to a maximum conversion of approximately $17 \%$ at the eighth pulse (Fig. 11(b)). The steady-state evolved heat was $30 \mathrm{~kJ} / \mathrm{mol}$ lower than that obtained when using the Ir-in- $\mathrm{CeO}_{2}$. The higher $\mathrm{CO}_{2}$ production and lower evolved heat in the case of the $\mathrm{Ir}-\mathrm{on}-\mathrm{CeO}_{2}$ suggested that $\mathrm{CO}_{2}$ was produced via the reaction of adsorbed $\mathrm{CO}$ on exposed Ir sites with oxygen species directly attached to the $\mathrm{CeO}_{2}$. The weakly adsorbed $\mathrm{CO}$ and oxygen species on the support of the $\mathrm{Ir}$-in- $\mathrm{CeO}_{2}$ initially reacted to form $0.06 \mathrm{ml}$ of carbonates, and then proceeded to slowly generate $\mathrm{CO}_{2}$ through a redox cycle involving the $\mathrm{CeO}_{2}$.

It was found that the pretreatment of Ir-in- $\mathrm{CeO}_{2}$ by $\mathrm{CO}$ pulses produced both oxygen vacancies and carbonates, whose roles in $\mathrm{CO}$ oxidation were studied by in situ pulse microcalorimetry [88]. The initial increase in oxygen vacancies promoted the $\mathrm{CO}$ oxidation activity, and the highest activity was obtained in conjunction with a $1.5 \%$ level of oxygen vacancies. However, further increases favored the accumulation of strongly adsorbed carbonates on the Ir-in- $\mathrm{CeO}_{2}$ catalyst, which inhibited the adsorption and activation of $\mathrm{CO}$, and in turn lowered the activity.

Gupta and coworkers $[89,90]$ studied the CO methanation reaction on polycrystalline $\mathrm{Ru}$ and $\mathrm{Ru} / \mathrm{TiO}_{2}$ catalysts using pulse microcalorimetry. As compared with $\mathrm{Ru}$ metal, $\mathrm{Ru} / \mathrm{TiO}_{2}$ exhibited a lower evolved heat for $\mathrm{CO}$ adsorption with excess $\mathrm{H}_{2}$. The corresponding FT-IR results showed the formation of multi-carbonyl adsorbed species, such as $\mathrm{Ru}(\mathrm{CO})_{n}, \mathrm{RuH}(\mathrm{CO})_{n}$ and $\mathrm{RuH}(\mathrm{CO})_{(n-1)}$, in addition to both linear and bridged CO species on the $\mathrm{Ru} / \mathrm{TiO}_{2}$ catalyst, while only linear species existed on the polycrystalline Ru. Based on the results of FT-IR and microcalorimetry, the superior low temperature methanation activity exhibited by the $\mathrm{Ru} / \mathrm{TiO}_{2}$ was attributed to the presence of multi-carbonyl species that required less energy to dissociate. This same group also studied $\mathrm{CO}$ oxidation on $\mathrm{Fe}_{2} \mathrm{O}_{3}$, polycrystalline $\mathrm{Au}$ and $\mathrm{Au} / \mathrm{Fe}_{2} \mathrm{O}_{3}$ catalysts $[91,92]$. The microcalorimetric results suggested that the $\mathrm{Fe}_{2} \mathrm{O}_{3}$ support in $\mathrm{Au} / \mathrm{Fe}_{2} \mathrm{O}_{3}$ was directly involved in the $\mathrm{CO}$ oxidation process. The heat evolved when $\mathrm{CO}$ was adsorbed on $\mathrm{Au}$ sites increased the local temperature at the interfaces between $\mathrm{Au}$ and $\mathrm{Fe}_{2} \mathrm{O}_{3}$, eventually accelerating the reaction between adsorbed $\mathrm{CO}$ and the support. Li et al. [93] assessed CO oxidation on a ferrihydrite $\left(\mathrm{FeO}_{x}\right)$-supported Au catalyst using pulse microcalorime-
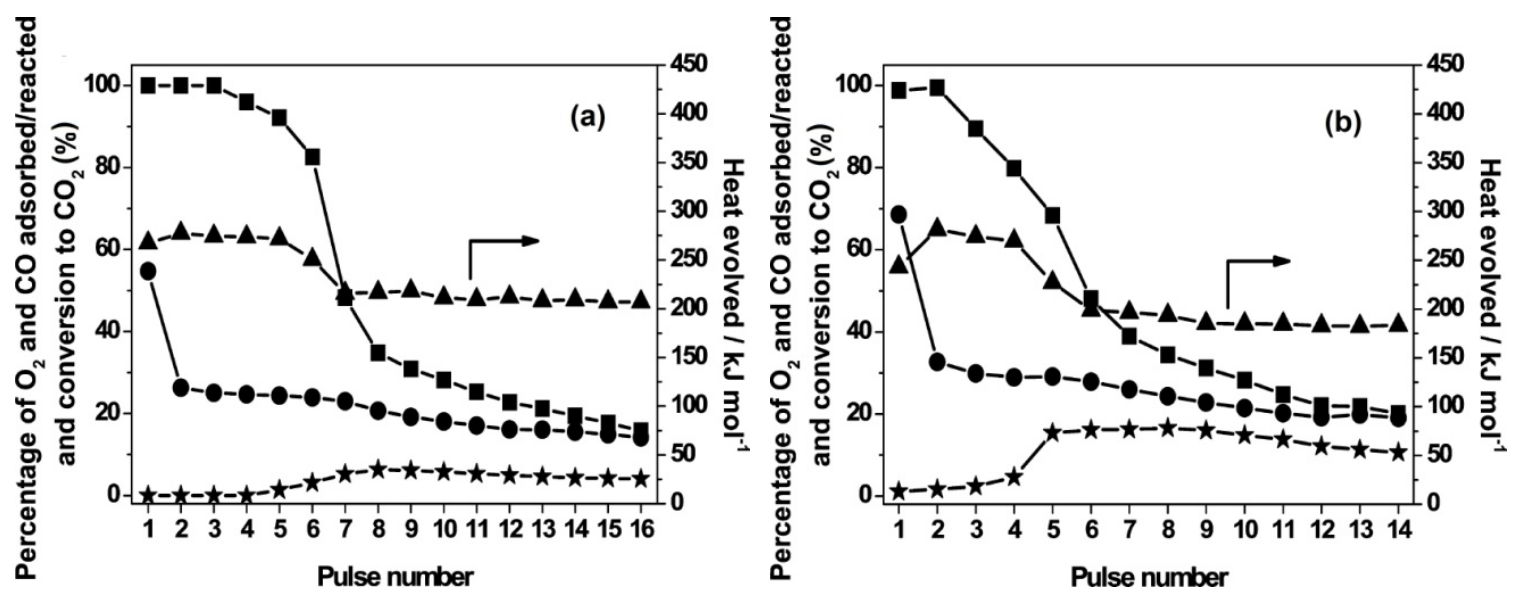

Fig. 11. Percentages of $\mathrm{O}_{2}(\mathbf{a})$ and $\mathrm{CO}(\mathbf{O})$ adsorbed/reacted, conversion to $\mathrm{CO}_{2}(\star)$, and corresponding heat evolved $(\mathbf{\Delta})$ with increasing $\mathrm{CO}+\mathrm{O}_{2}$ (2:1) pulses over (a) Ir-in- $\mathrm{CeO}_{2}$ and (b) $\mathrm{Ir}-\mathrm{on}-\mathrm{CeO}_{2}$ at $40{ }^{\circ} \mathrm{C}[26]$. 
try. A sequential microcalorimetric experiment was performed with alternating $\mathrm{CO}$ and $\mathrm{O}_{2}$ pulses. $\mathrm{CO}_{2}$ was produced with $\mathrm{CO}$ pulses, suggesting the reaction of surface lattice oxygen with CO. Subsequent pulses of $\mathrm{O}_{2}$ generated $400 \mathrm{~kJ} / \mathrm{mol}$ of heat, consistent with the transformation heat of $\mathrm{Fe}^{2+}$ to $\mathrm{Fe}^{3+}$ [87], indicating that the surface lattice oxygen on the ferrihydrite was supplemented by atmospheric oxygen to complete the redox cycle for CO oxidation.

\subsubsection{Assessments of reaction energetics by flow-through microcalorimetry}

Considering the potential application of the exothermic hydrogen recombination reaction $\left(\mathrm{H}_{2}+\mathrm{O}_{2} \rightarrow \mathrm{H}_{2} \mathrm{O}\right)$ to passive autocatalytic recombination (PAR) technology, Lalik et al. [94] studied the anomalous heat evolution of Pd-based catalysts by gas flow-through microcalorimetry and observed thermokinetic oscillations during the reaction process. The anomalous evolved heat reached a maximum of $700 \mathrm{~kJ} / \mathrm{mol} \mathrm{H}_{2}$, a value that was much higher than the standard enthalpy value of 242 $\mathrm{kJ} / \mathrm{mol} \mathrm{H}_{2}$ for the formation of gaseous water. These results indicated that it is important to consider the anomalous thermal effects that can appear abruptly during the hydrogen recombination reaction when designing a PAR reactor.

This group also investigated the activity and deactivation of the $\mathrm{H}_{2}+\mathrm{O}_{2}$ recombination reaction on $\mathrm{Al}_{2} \mathrm{O}_{3}$ and $\mathrm{SiO}_{2}$-supported Pd-Pt [95], alkali (Li, Cs)-doped $\mathrm{Pd} / \mathrm{Al}_{2} \mathrm{O}_{3}$ [96] and $\mathrm{Pd}-\mathrm{Au}$ catalysts [97]. An inverse relationship was established between the reaction energetics and $\mathrm{H}_{2}$ conversion (Fig. 12). That is, $\mathrm{H}_{2}$ conversion was found to decrease with increases in the reaction energetics, an effect possibly originating from the contribution of the adsorption of water and other oxygen-containing species such as $\mathrm{OH}$ formed during the reaction. These strongly adsorbed species suppressed the activity of the hydrogen combination reaction. Both the characteristics of the support and the type of metal were determined to affect the binding strength for water and, in turn, the activity. The most promising catalysts were silica-supported Pd-Pt bimetallic materials, which exhibited the lowest evolved reaction heats [95]. The addition of $\mathrm{Li}$ and $\mathrm{Cs}$ accelerated the deactivation of the $\mathrm{Pd} / \mathrm{Al}_{2} \mathrm{O}_{3}$ during the recombination reaction of $\mathrm{H}_{2}$ and $\mathrm{O}_{2}$. Microcalorimetric studies indicated that $\mathrm{Li}$ and $\mathrm{Cs}$ showed high adsorption strengths for water, leading to coverage of the active sites and therefore decreased stability [96]. In comparison, the relatively weak interactions of $\mathrm{H}_{2} \mathrm{O} / \mathrm{OH}$ with a $\mathrm{Pd}-0.1 \mathrm{Au} / \mathrm{SiO}_{2}$ catalyst resulted in nearly stable activity throughout the $\mathrm{H}_{2}$ and $\mathrm{O}_{2}$ recombination reaction [97].

The standard reaction enthalpy of a given reaction can be calculated according to the formation enthalpies of products and reactants. However, the reaction energetics measured by microcalorimetry are often different from the standard values. These differences are primarily due to the fact that the measured heats result from the contributions of all steps in the catalytic cycle. Furthermore, the energetics of different steps, which can be related to the structures and composition of catalysts, also affect the measured energetics. The interpretation of the data obtained from a reaction can therefore provide insights into the catalytic reaction process, and even the structure-reactivity relationship. However, the biggest challenge lies in interpreting the reaction energetics, which are much more complex than adsorption energetics. Fundamental information, such as adsorption heats, as well as thermochemical calculations are required to properly understand the reaction thermal data $[26,88]$, and complementary DFT calculationsare beneficial in this regard [95,97]. In situ FT-IR is also helpful for determining the nature of adsorption/reaction species [90]. Thus, to better interpret the reaction energetics, microcalorimetry should be combined with other characterization techniques such as FT-IR in a single apparatus to allow the simultaneous study of adsorption/reaction processes. Investigations of such setups are currently under way in our laboratory.

\section{Conclusions and outlook}

Microcalorimetry can provide insights into the nature of the interactions between adsorbates and catalyst surfaces that are difficult to obtain with other techniques. Two types of microcalorimetric setups have been developed, one of the most widely used being adsorption microcalorimetry, which can assess adsorption energetics on supported catalysts using probe molecules. Microcalorimetric setups operating in the flow-through and pulse modes can study the adsorption or reaction of more than one compound, and therefore extend the
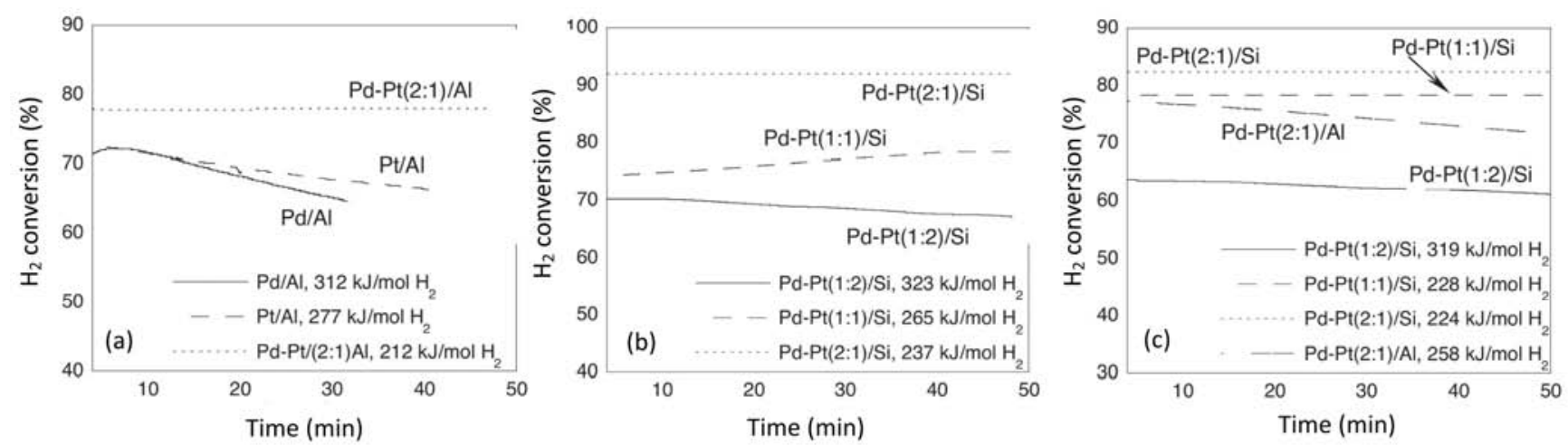

Fig. 12. The hydrogen and oxygen recombination process as monitored using a gas flow-through microcalorimeter in conjunction with (a) $2 \%$ $\mathrm{Pd} / \mathrm{Al}_{2} \mathrm{O}_{3}, 2 \% \mathrm{Pt} / \mathrm{Al}_{2} \mathrm{O}_{3}$ and $1 \% \mathrm{Pd}-\mathrm{Pt}(1: 1) / \mathrm{Al}_{2} \mathrm{O}_{3}$, (b) $2 \% \mathrm{Pd}-\mathrm{Pt}(2: 1) / \mathrm{SiO}_{2}, 2 \% \mathrm{Pd}-\mathrm{Pt}(1: 1) / \mathrm{SiO}_{2}$ and $2 \% \mathrm{Pd}-\mathrm{Pt}(1: 2) / \mathrm{SiO} \mathrm{O}_{2}$ catalysts, and (c) silica and alumina-supported Pd-Pt bimetallic catalysts heated at $150{ }^{\circ} \mathrm{C}$ under a $\mathrm{N}_{2}$ flow [95]. 
applications of microcalorimetry from adsorption energetics to reaction energetics. These versatile microcalorimetric setups allow the acquisition of energy data that are crucial to catalysis research.

One of the goals of catalysis is to design new catalysts with optimized surface structures so as to adjust the adsorption properties and therefore the catalytic reactivity. In conjunction with the results of catalytic reactions, adsorption/reaction energetics measured by microcalorimetry can be correlated with the catalytic performance to determine the most suitable active sites for catalytic reactions, which is beneficial in this design process. Various successful applications of this technique have been presented in this review, and we trust that this valuable research direction will proceed and lead to significant applications of microcalorimetry in heterogeneous catalysis. In addition, some initial explorations indicate that insights into reaction mechanisms and structure-activity relationships can be obtained from such studies of reaction energetics.

Microcalorimetry does present some limitations. Firstly, the microcalorimetric setup is usually complex and the experiments can be time-consuming. Secondly, the energetic information obtained, especially in the case of complex molecules, is often complicated and perhaps difficult to interpret, especially when multiple adsorbed species are formed on the catalyst surface. Therefore, microcalorimetry must be used in combination with other characterization techniques that can probe the nature of surface species. In future, it will become even more important to combine microcalorimetry with surface spectro- scopic investigations to understand the energetics of the catalytic reaction. One of the most promising methods is the combination of microcalorimetry with other characterization technologies in one setup so as to probe the adsorption and reaction processes simultaneously. Theoretical analysis can also be used as complementary method to assist in understanding the manner in which the reactants adsorb and react to form products through various elementary steps.

Some newer developments in microcalorimetry have led to energetic measurements in new catalytic areas [98]. As an example, isothermal titration calorimetry has been applied in the fields of homogeneous catalysis [99] and catalyst preparation [100]. We believe that such ongoing developments in instrumentation and research will enhance the power and the applicability of microcalorimetry with regard to catalysis research.

\section{References}

[1] P. Sabatier, Revue Déconomie Industrielle, Valbonne, 1913, 31, 100-111.

[2] K. W. Kolasinski, Surface Science: Foundations of Catalysis and Nanoscience, 3rd ed., John Wiley \& Sons, Ltd, Chichester, 2012, 185-228.

[3] N. Cardona-Martinez, J. A. Dumesic, Adv Catal., 1992, 38, 149-244.

[4] P. C. Gravelle, Catal. Rev.-Sci. Eng., 1977, 16, 37-110.

[5] S. Gaisford, V. Kett, P. Haines, Principles of Thermal Analysis and Calorimetry, 2nd ed, The Royal Society of Chemistry, Cambridge, 2016,

\section{Graphical Abstract}

Chin. J. Catal., 2016, 37: 2039-2052 doi: 10.1016/S1872-2067(16)62578-0

Adsorption/reaction energetics measured by microcalorimetry and correlated with reactivity on supported catalysts: A review

Lin Li, Jian Lin, Xiaoyu Li, Aiqin Wang, Xiaodong Wang*, Tao Zhang

Dalian Institute of Chemical Physics, Chinese Academy of Sciences; University of Chinese Academy of Science

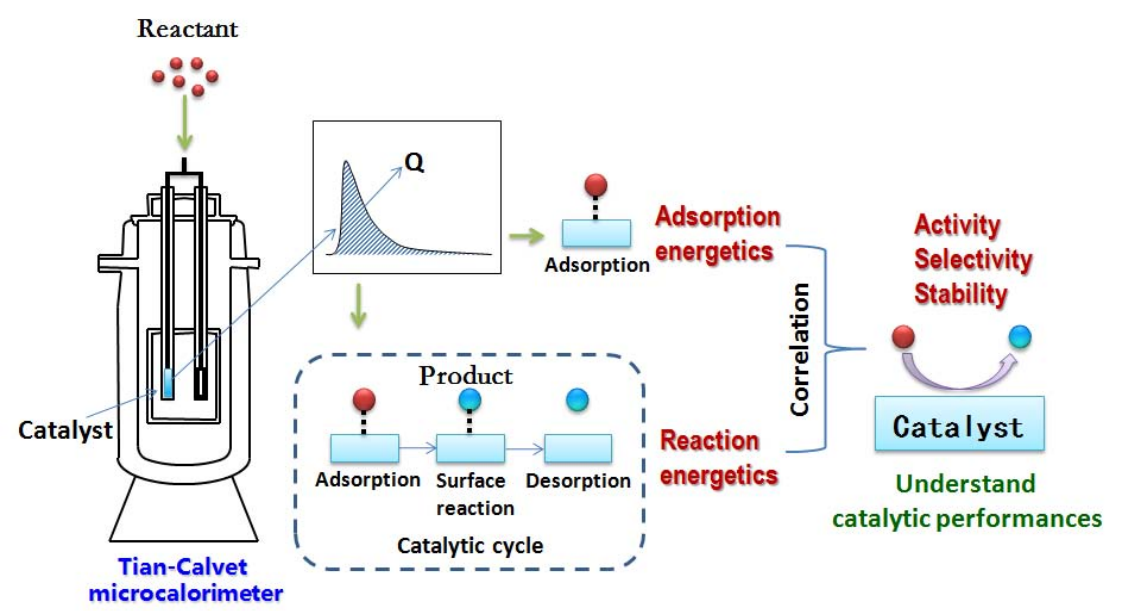

The interactions between molecules and catalyst surfaces that determine the course of a catalytic reaction are accompanied by the evolution of heat. The adsorption heat outputs measured by microcalorimetry can therefore provide insights into the catalytic performance when combined with the results of reaction rate data. The applications, advantages and shortcomings of microcalorimetry in the field of catalysis are discussed and summarized in this review. 
[6] A. Auroux, A. Gervasini, J. Phys. Chem., 1990, 94, 6371-6379.

[7] A. Auroux, Top. Catal., 2002, 19, 205-213.

[8] E. L. Kunkes, D. A. Simonetti, J. A. Dumesic, W. D. Pyrz, L. E. Murillo, J. G. G. Chen, D. J. Buttrey, J. Catal., 2008, 260, 164-177.

[9] S. Cerny, Surf. Sci. Rep., 1996, 26, 3-59.

[10] W. A. Brown, R. Kose, D. A. King, Chem. Rev., 1998, 98, 797-832.

[11] O. Lytken, W. Lew, C. T. Campbell, Chem. Soc. Rev., 2008, 37, 2172-2179.

[12] B. E. Spiewak, J. A. Dumesic, Thermochim. Acta, 1998, 312, 95-104.

[13] V. E. Ostrovskii, J. Therm. Anal. Calorim., 2009, 95, 609-622.

[14] A. Guerrero-Ruiz, A. Maroto-Valiente, M. Cerro-Alarcon, B. Bachiller-Baeza, I. Rodriguez-Ramos, Top. Catal., 2002, 19, 303-311.

[15] B. E. Handy, S. B. Sharma, B. E. Spiewak, J. A. Dumesic, Meas. Sci. Technol., 1993, 4, 1350-1356.

[16] B. E. Spiewak, J. A. Dumesic, Thermochim. Acta, 1997, 290, 43-53.

[17] V. Garcia-Cuello, J. C. Moreno-Piraján, L. Giraldo-Gutiérrez, K. Sapag, G. Zgrablich, Microporous Mesoporous Mater., 2009, 120, 239-245.

[18] Y. Kobayashi, Q. X. Li, D. Z. Wang, F. Wang, Rev. Sci. Instrum., 2014, 85, 034101.

[19] V. Garcia-Cuello, J. C. Moreno-Pirajan, L. Giraldo-Gutierrez, K. Sapag, G. Zgrablich, J. Therm. Anal. Calorim., 2009, 97, 711-715.

[20] F. Siperstein, R. J. Gorte, A. L. Myers, Langmuir, 1999, 15, 1570-1576.

[21] L. Li, X. D. Wang, J. Y. Shen, L. X. Zhou, T. Zhang, Chin. J. Catal., 2003, 24, 872-876.

[22] B. E. Spiewak, R. D. Cortright, J. A. Dumesic, J. Catal., 1998, 176, 405-414.

[23] A. J. Groszek, Thermochim. Acta, 1998, 312, 133-143.

[24] E. Lalik, R. Mirek, J. Rakoczy, A. Groszek, Catal. Today, 2006, 114, 242-247.

[25] N. D. Gangal, N. M. Gupta, R. M. Iyer, J. Catal., 1990, 126, 13-25.

[26] J. Lin, L. Li, Y. Q. Huang, W. S. Zhang, X. D. Wang, A. Q. Wang, T. Zhang, J. Phys. Chem. C, 2011, 115, 16509-16517.

[27] M. Maciejewski, A. Baiker, in: E. B. Michael, K. G. Patrick eds., Handbook of Thermal Analysis and Calorimetry, Elsevier Science B.V., Amsterdam, 2008, 5, 93-132.

[28] B. Lindström, L. J. Pettersson, Cattech, 2003, 7, 130-138.

[29] B. B. Bardin, S. V. Bordawekar, M. Neurock, R. J. Davis, J. Phys. Chem. B, 1998, 102, 10817-10825.

[30] D. Tichit, M. H. Lhouty, A. Guida, B. H. Chiche, F. Figueras, A. Auroux, D. Bartalini, E. Garrone, J. Catal., 1995, 151, 50-59.

[31] A. Guerrero-Ruiz, P. Badenes, I. Rodríguez-Ramos, Appl. Catal. A, 1998, 173, 313-321.

[32] M. Boudart, Chem. Rev., 1995, 95, 661-666.

[33] G. Yaluris, R. B. Larson, J. M. Kobe, M. R. Gonzalez, K. B. Fogash, J. A. Dumesic, J. Catal., 1996, 158, 336-342.

[34] A. Auroux, Top. Catal., 1997, 4, 71-89.

[35] W. Alharbi, E. F. Kozhevnikova, I. V. Kozhevnikov, ACS Catal., 2015, 5, 7186-7193.

[36] D. Stošić, S. Bennici, J. L. Couturier, J. L. Dubois, A. Auroux, Catal. Commun., 2012, 17, 23-28.

[37] D. Stošić, S. Bennici, S. Sirotin, P. Stelmachowski, J. L. Couturier, J. L. Dubois, A. Travert, A. Auroux, Catal. Today, 2014, 226, 167-175.

[38] Y. D. Xia, W. M. Hua, Z. Gao, Appl. Catal. A, 1999, 185, 293-300.

[39] K. B. Fogash, G. Yaluris, M. R. Gonzalez, P. Ouraipryvan, D. A. Ward, E. I. Ko, J. A. Dumesic, Catal. Lett., 1995, 32, 241-251.

[40] X. R. Chen, Y. Q. Du, C. L. Chen, N. P. Xu, C. Y. Mou, Catal. Lett., 2006, 111, 187-193.

[41] G. M. Kumaran, S. Garg, M. Kumar, N. Viswanatham, J. K. Gupta, L.
D. Sharma, G. M. Dhar, Energy Fuels, 2006, 20, 2308-2313.

[42] N. R. Shiju, D. R. Brown, K. Wilson, G. Rothenberg, Top. Catal., 2010, 53, 1217-1223.

[43] R. Kourieh, S. Bennici, M. Marzo, A. Gervasini, A. Auroux, Catal. Commun., 2012, 19, 119-126.

[44] R. Kourieh, V. Rakic, S. Bennici, A. Auroux, Catal. Commun., 2013, 30, 5-13.

[45] S. H. Hu, M. W. Xue, H. Chen, J. Y. Shen, Chem. Eng. J., 2010, 162, 371-379.

[46] H. Chen, M. W. Xue, S. H. Hu, J. Y. Shen, Chem. Eng. J., 2012, 181, 677-684.

[47] J. Zhao, H. Chen, J. Xu, J. Y. Shen, J. Phys. Chem. C, 2013, 117, 10573-10580.

[48] S. H. Hu, M. W. Xue, H. Chen, Y. L. Sun, J. Y. Shen, Chin. J. Catal., 2011, 32, 917-925.

[49] M. W. Xue, H. Chen, H. L. Zhang, A. Auroux, J. Y. Shen, Appl. Catal. A, 2010, 379, 7-14.

[50] P. Lauriol-Garbey, G. Postole, S. Loridant, A. Auroux, V. Belliere-Baca, P. Rey, J. M. M. Millet, Appl. Catal. B, 2011, 106, 94-102.

[51] D. Meloni, M. F. Sini, M. G. Cutrufello, R. Monaci, E. Rombi, I. Ferino, J. Therm. Anal. Calorim., 2012, 108, 783-791.

[52] R. Kourieh, L. Retailleau, S. Bennici, A. Giroir-Fendler, A. Auroux, Catal. Lett., 2013, 143, 74-83.

[53] T. R. Brueva, I. V. Mishin, G. I. Kapustin, Thermochim. Acta, 2001, 379, 15-23.

[54] N. Viswanadham, L. Dixit, J. K. Gupta, M. O. Garg, J. Mol. Catal. A, 2006, 258, 15-21.

[55] C. P. Nicolaides, H. H. Kung, N. P. Makgoba, N. P. Sincadu, M. S. Scurrell, Appl. Catal. A, 2002, 223, 29-33.

[56] D. Stosic, S. Bennici, S. Sirotin, C. Calais, J. L. Couturier, J. L. Dubois, A. Travert, A. Auroux, Appl. Catal. A, 2012, 447, 124-134.

[57] R. D. Cortright, J. A. Dumesic, J. Catal., 1994, 148, 771-778.

[58] R. D. Cortright, J. A. Dumesic, J. Catal., 1995, 157, 576-583.

[59] B. E. Spiewak, P. Levin, R. D. Cortright, J. A. Dumesic, J. Phys. Chem., 1996, 100, 17260-17265.

[60] S. B. Sharma, P. Ouraipyvan, H. A. Nair, P. Balaraman, T. W. Root, J. A. Dumesic, J. Catal., 1994, 150, 234-242.

[61] R. Naumann d'Alnoncourt, M. Kurtz, H. Wilmer, E. Löffler, V. Hagen, J. Shen, M. Muhler, J. Catal., 2003, 220, 249-253.

[62] A. Guerrero-Ruiz, E. Gallegos-Suarez, L. Gonzalo-Chacon, I. Rodriguez-Ramos, Thermochim. Acta, 2013, 567, 112-117.

[63] J. L. Eslava, A. Iglesias-Juez, G. Agostini, M. Fernandez-Garcia, A. Guerrero-Ruiz, I. Rodriguez-Ramos, ACS Catal., 2016, 6, 1437-1445.

[64] M. S. Chen, D. W. Goodman, Acc. Chem. Res., 2006, 39, 739-746.

[65] N. Lopez, T. V. W. Janssens, B. S. Clausen, Y. Xu, M. Mavrikakis, T. Bligaard, J. K. Nørskov, J. Catal., 2004, 223, 232-235.

[66] V. Bolis, in: Calorimetry and Thermal Methods in Catalysis, ed. A. Auroux, Springer Berlin Heidelberg, Berlin, Heidelberg, 2013, 505-519.

[67] H. A. Prescott, Z. J. Li, E. Kemnitz, A. Trunschke, J. Deutsch, H. Lieske, A. Auroux, J. Catal., 2005, 234, 119-130.

[68] A. Guerrero-Ruiz, S. W. Yang, Q. Xin, A. Maroto-Valiente, M. Benito-Gonzalez, I. Rodriguez-Ramos, Langmuir, 2000, 16, 8100-8106.

[69] X. T. Wang, L. Li, Y. Q. Huang, X. D. Wang, T. Zhang, Chin. J. Catal., 2008, 29, 1231-1236.

[70] J. M. Arce-Ramos, L. C. Grabow, B. E. Handy, M. G. Cardenas-Galindot, J. Phys. Chem. C, 2015, 119, 15150-15159.

[71] R. He, H. Kusaka, M. Mavrikakis, J. A. Dumesic, J. Catal., 2003, 217, 209-221.

[72] R. Alcala, J. W. Shabaker, G. W. Huber, M. A. Sanchez-Castillo, J. A. 
Dumesic, J. Phys. Chem. B, 2005, 109, 2074-2085.

[73] L. Li, X. D. Wang, A. Q. Wang, J. Y. Shen, T. Zhang, Thermochim. Acta, 2009, 494, 99-103.

[74] S. Wrabetz, X. B. Yang, G. Tzolova-Muller, R. Schlogl, F. C. Jentoft, J. Catal., 2010, 269, 351-358.

[75] K. Amakawa, J. Krohnert, S. Wrabetz, B. Frank, F. Hemmann, C. Jager, R. Schlogl, A. Trunschke, ChemCatChem, 2015, 7, 4059-4065.

[76] R. Arrigo, M. E. Schuster, S. Wrabetz, F. Girgsdies, J. P. Tessonnier, G. Centi, S. Perathoner, D. S. Su, R. Schlogl, ChemSusChem, 2012, 5, 577-586.

[77] Y. Wang, J. Zhao, T. F. Wang, Y. X. Li, X. Y. Li, J. Yin, C. Y. Wang, J. Catal., 2016, 337, 293-302.

[78] R. H. Cheng, Y. Y. Shu, M. Y. Zheng, L. Li, J. Sun, X. D. Wang, T. Zhang, J. Catal., 2007, 249, 397-400.

[79] O. Mihai, D. Creaser, L. Olsson, Catalysts, 2016, 6(5), 73/1-73/12.

[80] J. Zhao, H. Chen, X. C. Tian, H. Zang, Y. C. Fu, J. Y. Shen, J. Catal., 2013, 298, 161-169.

[81] J. M. Guil, N. Homs, J. Llorca, P. R. de la Piscina, J. Phys. Chem. B, 2005, 109, 10813-10819.

[82] L. Chen, J. Y. Shen, J. Catal., 2011, 279, 246-256.

[83] G. X. Pei, X. Y. Liu, A. Q. Wang, L. Li, Y. Q. Huang, T. Zhang, J. W. Lee, B. W. L. Jang, C. Y. Mou, New J. Chem., 2014, 38, 2043-2051.

[84] G. X. Pei, X. Y. Liu, A. Q. Wang, A. F. Lee, M. A. Isaacs, L. Li, X. L. Pan, X. F. Yang, X. D. Wang, Z. J. Tai, K. Wilson, T. Zhang, ACS Catal,, 2015, 5, 3717-3725.

[85] H. R. Zhou, X. F. Yang, L. Li, X. Y. Liu, Y. Q. Huang, X. L. Pan, A. Q. Wang, J. Li, T. Zhang, ACS Catal., 2016, 6, 1054-1061.

[86] C. M. Y. Yeung, K. M. K. Yu, Q. J. Fu, D. Thompsett, M. I. Petch, S. C. Tsang, J. Am. Chem. Soc., 2005, 127, 18010-18011.

[87] D. R. Lide, CRC Handbook of Chemistry and Physics, CRC Press Incorpration, Boca Raton, Florida, 84th ed., 2003-2004, Chapter 4, Section 5 .
[88] J. Lin, Y. Q. Huang, L. Li, A. Q. Wang, W. S. Zhang, X. D. Wang, T. Zhang, Catal. Today, 2012, 180, 155-160.

[89] V. P. Londhe, N. M. Gupta, J. Catal., 1997, 169, 415-422.

[90] N. M. Gupta, V. P. Londhe, V. S. Kamble, J. Catal., 1997, 169, 423-437.

[91] A. K. Tripathi, V. S. Kamble, N. M. Gupta, J. Catal., 1999, 187, 332-342.

[92] N. M. Gupta, A. K. Tripathi, J. Catal., 1999, 187, 343-347.

[93] L. Li, A. Q. Wang, B. T. Qiao, J. Lin, Y. Q. Huang, X. D. Wang, T. Zhang, J. Catal., 2013, 299, 90-100.

[94] E. Lalik, A. Drelinkiewicz, R. Kosydar, T. Szumełda, E. Bielańska, D. Groszek, A. Iannetelli, M. Groszek, Ind. Eng. Chem. Res.,2015, 54, 7047-7058.

[95] E. Lalik, R. Kosydar, R. Tokarz-Sobieraj, M. Witko, T. Szumełda, M. Kołodziej, W. Rojek, T. Machej, E. Bielańska, A. Drelinkiewicz, Appl. Catal. A, 2015, 501, 27-40.

[96] E. Lalik, A. Drelinkiewicz, R. Kosydar, W. Rojek, T. Machej, J. Gurgul, T. Szumelda, M. Kolodziej, E. Bielanska, Int. J. Hydrogen Energy, 2015, 40, 16127-16136.

[97] E. Lalik, A. Drelinkiewicz, R. Kosydar, R. Tokarz-Sobieraj, M. Witko, T. Szumelda, J. Gurgul, D. Duraczynska, Appl. Catal. A, 2016, 517, 196-210.

[98] M. C. Crowe, C. T. Campbell, in: Annual Review of Analytical Chemistry, Vol 4, eds. R. G. Cooks, E. S. Yeung, Annual Reviews, Palo Alto, 2011, 4, 41-58.

[99] E. G. Moschetta, K. M. Gans, R. M. Rioux, J. Catal., 2014, 309, $11-20$.

[100] M. E. Strayer, J. M. Binz, M. Tanase, S. M. Kamali Shahri, R. Sharma, R. M. Rioux, T. E. Mallouk, J. Am. Chem. Soc., 2014, 136, 5687-5696.

\title{
微量热技术测量担载型催化剂的吸附/反应能量并与反应性能相关联: 综述
}

\author{
李 林, 林 坚 ${ }^{\mathrm{a}}$, 李签玉 ${ }^{\mathrm{a}, \mathrm{b}}$, 王爱琴 ${ }^{\mathrm{a}}$, 王晓东 ${ }^{\mathrm{a},}$, 张 涛 $^{\mathrm{a}}$ \\ a 中国科学院大连化学物理研究所催化基础研究国家重点实验室, 辽宁大连 116023 \\ ${ }^{\mathrm{b}}$ 中国科学院大学, 北京 100049
}

摘要: 多相催化反应过程伴随着反应分子与催化剂表面之间的相互作用. 这种相互作用强度与催化剂的反应性能密切相 关. 根据萨巴蒂尔原理(Sabatier principle), 性能最优的催化剂与反应中间体之间应该具有适中的相互作用强度, 一方面促 进反应物活化, 另一方面允许产物脱附. 这样, 测量和研究反应分子与催化剂之间的相互作用强度对于理解催化反应性能 有非常重要的意义.

当气体反应物接触到催化剂表面会伴随着热量的产生, 该热量被定义为吸附热, 并与吸附物种与催化剂之间形成的化 学键强度直接相关. 吸附热通常可以通过程序升温脱附(TPD)等方法间接获得. 但是这些方法建立在吸附物种能够可逆地 吸附和脱附的假设基础上. 在实际的程序升温过程中, 吸附物种通常会发生分解, 并伴随着固体催化剂的重构等现象. 因 此, 采用基于Tian-Calvet原理的热流量热计直接测量担载催化剂的吸附热是最可靠的吸附热测量方法.

基于热流量热计测量的微量热技术的一个重要优点是采用合适的探针分子吸附, 可以获得担载型催化剂表面吸附活 性中心的数量、强度及其能量分布的定量信息. 比如, 采用碱性探针分子 $\mathrm{NH}_{3}$ 或者吡啶, 酸性探针分子 $\mathrm{CO}_{2}$ 或 $\mathrm{SO}_{2}$ 能够定 量催化剂上酸-碱位的强度和数量, 而金属催化剂活性中心可以应用 $\mathrm{H}_{2}$ 或 $\mathrm{CO}$ 进行探测. 当这些催化剂活性中心的定量表 征结果与催化剂的反应活性测试结果相关联时,可以区分不同强度活性中心的反应性能, 并为提高和改进催化剂性能提供 研制方向.

相对于 $\mathrm{NH}_{3}$ 或 $\mathrm{CO}$ 等小分子气体, 催化反应的反应物、产物或可能的中间体通常都是复杂分子, 程序升温技术测量它 们的吸附热时, 这些分子通常会发生分解, 限制了其吸附热的测量和研究. 微量热技术能够直接测量这些分子的吸附热. 因此, 与催化反应活性相关联, 反应物、产物或可能的中间体的吸附能量的测量和研究有利于更直接地认识催化剂的反应 
性能.

在催化反应循环过程中, 除了吸附, 还包括表面反应和脱附步骤. 这些步骤也伴随着吸附物种与催化剂之间键的形成 与转换, 并以热量的形式表现出来. 测量这些热量对于认识催化反应过程, 理解催化反应机理有重要的意义. 热流量热计 与催化微反系统相结合, 为催化反应过程能量的测量和研究提供了可能.

尽管微量热技术在测量担载型催化剂的吸附/反应能量并与反应性能相关联方面有其独特的优势, 但是为了更好地用 于催化研究, 应该结合其它的表征技术(比如红外)确定吸附或反应物种的本质, 结合理论计算对量热结果进行更好地补充 和认识.

本文综述了担载型催化剂的吸附/反应能量与反应性能关联的研究进展, 指出了微量热技术在催化研究中的优势、不 足, 以及未来的研究方向.

关键词: 催化; 微量热; 反应性能; 能量; 键强; 催化剂表征

收稿日期: 2016-09-22. 接受日期: 2016-10-14. 出版日期: 2016-12-05.

*通讯联系人. 电话: (0411)84379680; 传真: (0411)84685940; 电子信箱: xdwang@dicp.ac.cn

基金来源：国家自然科学基金(21573232，21576251，21676269); 科技部重大研究计划(2016YFA0202801); 辽宁省科技厅院士基 金(2015020086-101).

本文的英文电子版由Elsevier出版社在ScienceDirect上出版(http://www.sciencedirect.com/science/journal/18722067). 